\title{
HOTEL MANAGEMENT CONTRACTS AND DEFICIENCIES IN OWNER-OPERATOR CAPITAL EXPENDITURE GOAL CONGRUENCY
}

\author{
Michael TURNER \\ Lecturer of Accounting \\ Faculty of Business, Economics \& Law \\ UQ Business School \\ University of Queensland \\ St. Lucia, Brisbane \\ AUSTRALIA \\ m.turner@business.uq.edu.au \\ Tel: 0733656583
}

and

\author{
Chris GUILDING \\ Professor of Hotel Management \\ Department of Tourism, Leisure, Hotel and Sport Management \\ Griffith University - Gold Coast Campus \\ Queensland \\ AUSTRALIA \\ C.Guilding@griffith.edu.au \\ Tel: 0755528790
}

\section{Corresponding Author: \\ Chris Guilding \\ C.Guilding@griffith.edu.au}

\section{Acknowledgement:}

The authors would like to acknowledge helpful suggestions provided by attendees at the Performance Measurement Association Conference in Dunedin, New Zealand, April 14 - 17, 2009, and also the detailed commentaries provided by three reviewers that have resulted in the paper being strengthened. 


\title{
HOTEL MANAGEMENT CONTRACTS AND DEFICIENCIES IN OWNER-OPERATOR CAPITAL EXPENDITURE GOAL CONGRUENCY
}

\begin{abstract}
A review of the findings of prior empirical research concerning hotel management contracts between owners and operators is undertaken. It is noted that management contracts have become increasingly commonplace in the international hotel sector and that gross revenue and gross operating profit are the most extensively used determinants of operator incentive fee remuneration. These findings present a platform for examining how revenue and gross operating profit are deficient in promoting owner-operator goal congruency. In light of this, return on investment (ROI) and residual income (RI) are examined as potential alternative determinants of operator reimbursement. While it is appears that both ROI and RI as determinants of hotel operator fees would represent an advance in promoting owner-operator goal congruency, a rationale outlining how residual income is preferable to ROI is outlined.
\end{abstract}

Keywords: Hotel management contract, return on investment, residual income, capital expenditure. 


\section{HOTEL MANAGEMENT CONTRACTS AND DEFICIENCIES IN OWNER-OPERATOR CAPITAL EXPENDITURE GOAL CONGRUENCY}

\section{INTRODUCTION}

Collier and Gregory (1995a) feel that capital budgeting research is particularly warranted in hotels due to their dual role of property and guest management and because of their high proportion of capital intensive assets. Further, hotels are vibrant organisations characterised by complex buildings that are costly to maintain (Chan, Lee, \& Burnett, 2001). The importance of these assets underscores the view that the most important budget in a hotel is the capital budget (Condon, Blaney, \& Harrington, 1996; Lynch, 2002).

Guilding (2003, 2006) notes heightened capital budgeting complexity in hotels operating with a management contract, because the capital outlay decision must traverse organisational boundaries in satisfying investment criteria of both owner and operator. Given the high incidence of owner-operator hotel management contracts and the particular governance challenges arising, Field (1995) expresses surprise at the minimal academic research directed towards furthering our appreciation of this idiosyncratic governance arrangement.

While there is a large literature concerning capital budgeting practice in hotels (e.g. BranderBrown, 1995; Collier \& Gregory, 1995a, 1995b; Damitio \& Schmidgall, 2002; DeFranco, 1997; Eder \& Umbreit, 1987; Eyster \& Geller, 1981; Field, 1995; Guilding, 2003, 2006; Guilding \& Hargreaves, 2003; Guilding \& Lamminmaki, 2007; T. Jones, 1998; Schmidgall \& Damitio, 1990; Schmidgall \& Ninemeier, 1987), few studies have investigated the particular capital budgeting issues arising in hotels governed by a management contract (Field, 1995; 
Guilding, 2003, 2006). This is surprising as Beals and Denton (2005, p. 144) contend that expectations concerning operators' appropriate expenditure of owners' money have been severely undermined by field observations and law court judgements. This beckons a fundamental examination of this critical aspect of the owner-operator relationship.

These factors provide the contextual motivation for this study. The study's objective is twofold. Firstly, it seeks to provide an examination of management contract provisions pertaining to hotel operator remuneration and to explicate shortcomings of these provisions in promoting owner-operator capital expenditure goal congruency. Secondly, it examines the relative merits of alternative determinants of hotel operator fees, such as return on investment and residual income. The importance of remunerating a hotel operator in a manner consistent with promoting owner-operator capital expenditure goal congruence becomes particularly evident when we recognise that it is the hotel operator that generally initiates capital expenditure proposals (Guilding, 2006). Should capital expenditure goal congruency be deficient, operators may fail to share with owners capital expenditure ideas that significantly serve owner interests, but are minimally aligned to their interests.

By exploring hotel owner-operator contractual relations, this study contributes to agency theory, as it focuses on exposing contractual problems arising when an agent (hotel operator) has the capacity to act in a self-interested manner that is inconsistent with the principal's (hotel owner) interests (Berle \& Means, 1962; Jensen \& Meckling, 1976). The agency model has been employed in a wide variety of business settings concerned with a range of issues, e.g., vertical integration (Walker \& Weber, 1984), executive compensation (Baker, Jensen, \& Murphy, 1988), and tender offers (Cotter \& Zenner, 1994). It has also been applied in a range of disciplinary contexts, e.g., accounting (Demski \& Feltham, 1978), marketing (Basu, Lai, 
Srinivasan, \& Staelin, 1985) and organisational behaviour (Eisenhardt, 1988)). This study concerns the owner-manager agency relationship which has been the dominant focus in agency theory based studies (Eisenhardt, 1989; Walsh \& Seward, 1990).

The authors are not aware of any prior academic work that provides a systematically conducted expose of the relative merits of hotel operator incentives used widely in hotel management contracts. We are also not aware of any prior consideration given to the extent to which ROI and residual income may represent preferable bases upon which to base hotel operators' fees. This paper's primary contribution is to provide a systematic examination of the shortcomings of conventional performance measures used to determine hotel operator fees and to advance the case that ROI and residual income represent alternative performance bases that would result in heightened levels of owner-operator goal alignment. The rationale provided offers considerable potential to stimulate further debate into hotel owner-operator contracting and to change the structure of operator fee incentive terms widely used in hotel management contracting. The paper can also be seen as representing a particular contribution to the application of agency theory in the hotel management context.

The remainder of the paper is structured as follows. The next section summarises findings of prior research suggesting increasing use of hotel management contracts. This is followed by an examination of the widespread use of operator fee determinants and also termination clause performance measures that undermine owner-operator capital expenditure goal congruency. An examination of the relative merits of return on investment and residual income as alternative operator fee incentive bases is then provided. The final section provides a concluding discussion and some suggestions for further research designed to extend insights concerning the dynamics of hotel management contracting provided herein. 


\section{GROWING INCIDENCE OF MANAGEMENT CONTRACTS}

Regardless of how a hotel's assets are owned, hotel owners face a number of choices regarding their operating structure. In many cases, the party that owns a hotel does not operate the hotel (Hayes \& Ninemeier, 2004). Considered internationally, the three main hotel operational methods are the owner-operator, franchise agreement and management contract (Gannon \& Johnson, 1997).

Hotel owners that choose to operate their hotel avoid any loss of control over day-to-day operations (Field, 1995). The use of the owner-operator hotel ownership structure is, however, dwindling in many developed Western markets, such as the U.S., Europe, Australia, and New Zealand (Gross-Turner, 1999; Ingram \& Baum, 1997; P. Jones, 1996; Phillips, 2003; Slattery, 1992). Further, there is little use of the hotel owner-operator structure in the burgeoning economies of India, China, and other parts of Asia (Haast, et al., 2006). As a result, usually only ‘flagship’ properties remain independently owned and operated (Gannon \& Johnson, 1997).

Garcia-Falcon and Medina-Munoz (1999, p. 106) define hotel franchising as an arrangement where:

For a fee, an independent hotel [i.e. owner-operator] adopts the franchiser's name and trademarks and receives services in return, including the preparatory steps of feasibility, site selection, financing, design, and planning. Almost all the advantages of the chain are available for the franchisee: mass purchasing, management consultation, wide advertising, central reservations, and systems designs. 
Despite relatively high franchising fees, studies show that in both developed and emerging markets, conditions are more supportive of franchising arrangements than owner-operator structures (see e.g. Fladmoe-Lindquist \& Laurent, 1995; Huszagh, Huszagh, \& McIntyre, 1992; Kedia, Ackerman, Bush, \& Justis, 1994; Shane, 1996).

Despite the well-established franchising model, recent surveys show that the third main hotel operational approach, the management contract, has become the most popular of the three options. The separation between ownership and management through the use of a hotel management is now widespread (Beals \& Denton, 2005; Corgel, 2007; Panvisavas \& Taylor, 2006) and is one of the driving mechanisms for the rapid internationalisation of hotels (Beattie, 1991; Dave, 1984; Dunning \& McQween, 1981; Eyster, 1997; Litteljohn, 1991; Litteljohn \& Beattie, 1992). Table 1 highlights the predominance of the management contract across North America, Europe and Asia in the late 1990s. Further, Slattery (1996) noted 75\% of listed Asian hotels operating under a management contract. Contractor and Kundu (1998) found $41 \%$ of US hotels had a management contract, while Smith Travel Research (2003) noted an increase to 55\%. Beals and Denton (2005), Panvisavas and Taylor (2006), and Corgel (2007) have provided further recent testimony to the increasing popularity of management contracts.

\section{INSERT TABLE 1 ABOUT HERE}

A management contract is essentially a written agreement between an owner and operator where the operator is appointed to operate and manage the hotel in the name of, on behalf of, and for the account of the owner. The contract includes a description of the operator's 
remuneration fee determination (Schlup, 2004). It enables a hotel owner to retain legal ownership of the hotel site, building, plant and equipment, furnishings and inventories, while the operator assumes responsibility for managing the hotel's day-to-day business (Guilding, 2003).

Management contracts do suffer, however, from some drawbacks. A fundamental problem concerns agency challenges, as the divorce of ownership and operation can create a volatile mix of economics and power manifested due to differing owner-operator time horizons (Beals, 1995; Beals \& Denton, 2005). It is generally held that operators focus on short-term cash flows while owners have more of a long-term orientation (Guilding, Kennedy, \& McManus, 2001; Lynch, 2002). This tension is widely referred to as the 'horizon problem' (Dechow \& Sloan, 1991; Ittner, Larker, \& Rajan, 1997; B. Johnson, 1987; Smith \& Watts, 1982) and can lead agents to promote low net present value (NPV) projects yielding relatively high short-term accounting earnings at the expense of higher NPV projects that yield lower short-term accounting earnings (Baber, Kang, \& Kumar, 1998). Operators also tend to focus on maximising their brand values and the longevity of their management contracts in order to increase the room stock under their management (Beals \& Denton, 2005; Haast, et al., 2006; Schiff, 2006). With regard to the brand value maximisation incentive, it is notable that a large proportion of a hotel company's assets are made up of goodwill associated with their brand name (Dev, Morgan, \& Shoemaker, 1995). The importance of hotel brand value signifies that operators have an incentive to support capital expenditures that are consistent with projecting a favourable brand image, even though the expenditure may provide limited equity value enhancement for the hotel owner. Consider, for example, a proposed hotel lobby refurbishment. On incremental cash flow grounds, the refurbishment expenditure may not be viable. However, in terms of improved brand alignment for the 
operating company, the proposed lobby refurbishment may be highly desirable. These examples of conflicting interests underscore the fact that management contracts are frequently associated with owner-operator agency conflict (Dimou, Chen, \& Archer, 2003).

\section{MANAGEMENT CONTRACTS AND OWNER-OPERATOR CAPITAL EXPENDITURE}

\section{GOAL CONGRUENCY}

Due to the considerable agency issues arising in the hotel management contract context, an owner's choice of operating company and the exact terms of a contract are among the most critical factors determining a hotel's long-term success (Horwath, 2006). Armitstead and Marusic (2006) note the imperative of designing management contracts that engender goal congruence. Berger (1997) comments on the particular importance of the operator's remuneration basis, which can be a source of significant tension between the contracting parties.

An operator's remuneration is widely referred to as a 'management fee' (Rushmore, 2002). Three basic management fee structures are found in practice: (1) a base fee only; (2) an incentive fee only; or (3) a base fee combined with an incentive fee (Goddard \& StandishWilkinson, 2002). The combination of a base and incentive fee is the most common.

With respect to the combined base and incentive fee structure, it has been conventional to view the base element as covering the management company's operating expenses, while the incentive fee contributes to the operator's profit (Rushmore, 2002). While the base fee can be a fixed amount, it is most usually determined as a percentage of gross revenue. This signifies that the term 'base fee' is something of a misnomer, as it is a variable amount that might be 
better viewed as an 'incentive fee', providing operators with an incentive to increase hotel revenue. Table 2 summarises the findings of prior studies concerned with ascertaining how hotel operator base fees are determined. It is evident from this table that internationally, the majority of management contract base fees are determined by gross revenue.

\section{INSERT TABLE 2 ABOUT HERE}

The continued widespread popularity of revenue determined operator base fees appears somewhat surprising given Feldman's (1995, p. 43) comment that they provide an incentive for operators to "blithely recommend expenditures that increase top-line revenues that never drop to the bottom line.” Two further noteworthy implications arise from remunerating operators based on hotel revenue:

1. Aligned to the issue noted by Feldman, operator remuneration based on revenue provides the operator with an incentive to promote capital expenditure proposals that maximise revenue, without necessarily positively impacting on profit. An operator with a base fee incentive of maximising revenue might attempt to promote a capital expenditure proposal that will increase revenues by $20 \%$ and carry a negligible (or even negative) impact on profit, at the expense of an alternative proposal that will increase revenue by $5 \%$ and profit by $10 \%$.

2. An operator with a remuneration based on revenue would have no incentive to initiate cost saving hotel capital expenditure proposals. An example of a cost saving capital expenditure that carries no implication for revenue would be the option of upgrading laundry facilities that will result in less laundry labour hours worked, reduced maintenance costs, reduced laundry detergent costs, reduced water consumption and reduced wear and tear to laundered items. Although this type of proposal may have 
the potential to carry a major positive impact on profit, the absence of an effect on revenue may cause an operator with a revenue maximising inducement to exclude it from capital expenditure proposals submitted to a hotel owner. ${ }^{1}$

Table 3 summarises prior research findings concerned with the determination of operator incentive fees. From this table it is apparent that most incentive fees are based on either a percentage of gross operating profit (GOP), GOP minus specific charges, cash flow or cash flow minus specific charges. There is a small incidence of incentive fees based on GOP relative to gross revenue, appreciated value of property, percentage above an owner's priority return, a percentage of GOP that exceeds a base fee amount, a percentage of net operating profit (NOP) over a fixed amount, or a percentage of the amount by which cumulative cash flow exceeds a cumulative set aside amount.

\section{INSERT TABLE 3 ABOUT HERE}

Emphasis attached to profit when determining an operator's incentive fee appears to have considerable potential to promote capital expenditure dysfunctionalism. Consider the case of two mutually exclusive projects: project A requiring an initial investment of $\$ 1,000,000$ and projected to return $\$ 50,000$ per annum, and project $B$ requiring an initial investment of $\$ 500,000$ and projected to return $\$ 45,000$ per annum. If an operator is remunerated according to a profit based incentive fee, it will prefer project A as it generates the highest profit. However, project B provides a superior return on investment of $9 \%(\$ 45,000 \div \$ 500,000 \mathrm{X}$

\footnotetext{
${ }^{1}$ These two implications (i.e., promoting revenue maximising projects with no regard given to profit impact, and no incentive to pursue cost cutting projects) will be mitigated where a hotel management contract also provides a separate profit based incentive. Nevertheless, even the presence of a small proportion of an operator's fee based exclusively on revenue will introduce a bias causing the operator to weight the importance of revenue maximisation more heavily than cost minimisation or profit maximisation. As the proportion of an operator's total remuneration that is revenue based is increased, so too will the extent of this bias.
} 
100) compared to project A's $5 \%(\$ 50,000 \div \$ 1,000,000 \mathrm{X} 100)$. Prior to taking this investment appraisal methodological analysis further, this simple scenario provides a clear indication that a hotel owner is likely to prefer project B, while an operator remunerated on a basis linked to profit can be expected to prefer project A.

As already noted, Table 3 highlights that some hotel operators' remuneration is based on GOP or cash flow minus one or more charges relating to asset investment. Remuneration bases that involve these types of deduction appear to provide a better basis for promoting owner-operator capital expenditure goal alignment. This is because they represent algorithms affording recognition to asset involvement in profit generation. Charges against profit or cash flow noted in Table 3 that recognise asset involvement in profit generation include: property taxes, insurance, FF\&E (furniture, fittings and equipment) reserve allocation, and debt service.

With respect to making a charge for the FF\&E reserve allocation, it is noted by Schlup (2004) that because the adequate maintenance of a hotel is also in the best interest of the operator, it appears fair that contributions to the FF\&E reserve be treated as operating expenses, signifying a reduced fee paid to operators remunerated on a profit basis. Understanding the implication for an operator when FF\&E reserve allocations are deducted from the profit figure used in determining incentive fee payments is complicated, however. To appreciate this we need to recognise that the FF\&E reserve allocation is generally set at around $3 \%$ of gross revenue (Brooke \& Denton, 2007; Phillips, 2003; Ransley \& Ingram, 2001). Consider the case of a hotel operator evaluating a capital expenditure opportunity that will provide a $\$ 1,000$ increase in revenue. If the operator is paid a 3\% of gross revenue base fee, they stand to benefit by $\$ 30$ (3\% of the $\$ 1,000$ increase in revenue). With respect to the operator's 
incentive fee, if the fee is based on profit minus a charge for FF\&E reserve allocation and if the allocation is set at 3\% of gross revenue, then an additional $\$ 30$ (3\% of $\$ 1,000$ ) will be allocated to the FF\&E reserve and deducted from the profit basis used for determining the incentive payment. Say that $10 \%$ of the adjusted profit is being provided to the operator as their incentive fee, the result of the $\$ 1,000$ increased revenue on the incentive fee paid is a reduction of only $\$ 3(\$ 1,000 \times 3 \% \times 10 \%){ }^{2}$ This worked example highlights the extent to which deducting FF\&E reserve allocations from GOP used in determining operator incentive fee payments contributes minimally to greater owner-operator capital expenditure goal congruency. Further, it is notable that the amount allocated to FF\&E reserve does not represent a good proxy for FF\&E capital expenditure, as it is widely noted that FF\&E reserve contributions fall some way short of the average annual capital expenditure required to maintain FF\&E (Barge \& Jacobs, 2001; Brooke \& Denton, 2007; Eyster, 1988, 1997; Ferguson \& Selling, 1985; Haast, Dickson, \& Braham, 2005; Mellen, Nylen, \& Pastorino, 2000; Ransley \& Ingram, 2001; Reichardt \& Lennhoff, 2003). ${ }^{3}$

Of the asset related deductions from GOP that are noted in Table 3, making a charge for debt service and return on equity both appear to lay the basis for greater owner-operator capital expenditure goal congruency relative to an FF\&E reserve allocation linked deduction. This is because they both represent an explicit charge for the full cost of any capital outlays made, signifying an operator incentive to minimise an owner's capital outlay. ${ }^{4}$

\footnotetext{
${ }^{2}$ In the interests of parsimony, we have assumed that the $\$ 1,000$ increase in revenue has not resulted in a change in profit. This simplifying assumption does not affect the rationale outlined.

${ }^{3}$ It is notable that widely deployed long-term loan restrictive covenants impose FF\&E reserve contribution requirements on hotel owners as a means of protecting lender interests.

${ }^{4}$ It should be noted that charges for debt and equity appear to be little used outside the U.S. Discussions with a specialist in the preparation of Australian hotel management contracts indicate that it is very rare for capital employed charges (whether relating to debt or equity) to be included in the calculation of the profit basis used to determine an operator's incentive fee.
} 
A second dimension of the management contract drawing on accounting metrics to promote owner-operator goal alignment concerns performance standards which, if not met, can be invoked by an owner as grounds for contract termination (Dutta, 2003; Haktanir \& Harris, 2005). This aspect of contracting can be a source of significant owner-operator conflict (Beals \& Denton, 2005). Despite this, the deployment of minimum performance standards in hotel management contracting is expected to increase commensurate with rising hotel operator competition levels (Goddard \& Standish-Wilkinson, 2002; Harris \& Mongiello, 2001; Rainsford, 1994). It is widely noted, however, that exclusive use of performance measures is unlikely to curb potential dysfunctional operator behaviour, because owners have limited capacity to extract all private information pertaining to performance (Baiman, 1990; Baiman, Evans, \& Noel, 1987; Magee, 1980). The findings of prior empirical research appraising the nature and incidence of operator performance measures are summarised in Table 4.

\section{INSERT TABLE 4 ABOUT HERE}

The only measures documented in Table 4 that have not already been considered are occupancy and revenue per available room (RevPAR). The relative merits of each are outlined in the hospitality management accounting normative literature (e.g. Jagels, 2007; Schmidgall, 2006). With respect to their implications for capital expenditure decision making, consistent with the rationale already outlined, occupancy and RevPAR both suffer from no recognition of capital outlay. If appraised on RevPAR and occupancy, an operator would have an inducement to rank a $\$ 50,000$ capital expenditure opportunity that results in a 2\% increase in occupancy and \$5 increase in RevPAR behind a \$1,000,000 outlay that results 
in a 3\% increase in occupancy and \$6 increase in RevPAR. Although the first option can be expected to provide the higher return on investment, it yields the lower occupancy and RevPAR. It should also be noted that emphasis on occupancy and RevPAR performance measures would likely raise the priority attached by an operator to accommodation related capital expenditures relative to expenditure on other hotel activities such as restaurant and bar.

Where an operator is performing poorly, the only other termination option for an owner is to invoke termination without a cause provisions. Prior research findings concerned with appraising the incidence and nature of such provisions are summarised in Table 5. This table highlights that around one-third of management contracts include termination without a cause provisions. Consistent with the challenge of activating operator performance measures, termination without a cause provisions are becoming increasingly difficult to invoke because of their extensive qualifications and caveats (Dickson, 2007). This underscores the importance of ensuring that a negotiated management contract is conducive to a high degree of owner-operator goal alignment. Management contract termination impediments in combination with deficient owner-operator goal congruence signify a high propensity for protracted hotel operational decision-making that is inconsistent with owner interests.

INSERT TABLE 5 ABOUT HERE

RETURN ON INVESTMENT AND RESIDUAL INCOME AS ALTERNATIVE DETERMINANTS OF OPERATOR FEES 
The foregoing analysis has highlighted widespread use of hotel operator remuneration bases that appear deficient with respect to promoting owner-operator capital expenditure goal congruency. We now turn to consider alternative performance measures that, a priori, represent inducement bases more consistent with promoting owner-operator capital expenditure goal congruency.

Generally accepted finance practice holds that the preferred investment appraisal criterion is NPV and that capital expenditure proposals are justifiable if they yield a projected positive NPV (Butler, Davis, Pike, \& Sharp, 1993; Payne, Carrington-Heath, \& Gale, 1999). Formulation of a NPV calculation requires the provision of projected cash flows. NPV would not be a good basis for determining hotel operator management fees, however. This is because operator management fees need to be based on objectively verifiable performance measures. Monitoring past achievements involves much less subjectivity than projected cash flow formulation. So although NPV is the preferred approach for evaluating capital expenditure proposals, it does not lend itself to gauging a hotel operator’s performance.

Two measures of past performance that give recognition to the amount of investment involved in generating a return and are widely discussed in the management accounting literature are return on investment (ROI) and residual income (RI) (Anthony \& Govindarajan, 2007; Langfield-Smith, Thorne, \& Hilton, 2003). ${ }^{5}$ Formulae for these measures follow: ${ }^{6}$ ROI $=$ Operating profit $\div$ Operating assets; or Operating profit $\div$ Sales $\mathrm{X}$ Sales $\div$ Operating assets

\footnotetext{
${ }^{5}$ Residual income formulations often appear under various names such as abnormal earnings (Ohlson, 1995) or Economic Value Added $\left(\mathrm{EVA}^{\circledR}\right)$, which is a technique popularised by the consulting firm Stern Stewart \& Co (Anthony \& Govindarajan, 2007; Biddle, Bowen, \& Wallace, 1997; Chen \& Dodd, 1997; Wallace, 1997).

${ }^{6}$ It should be noted that, in practice, there can be much variation in the way that companies define profit and assets. Profit can be profit before or after tax, earnings before interest and taxes (EBIT) or net profit. While assets may be defined as total assets or assets minus current liabilities.
} 


$$
\text { RI = Operating profit }- \text { (Cost of capital X Operating assets) }
$$

It can be seen from these formulae that ROI constitutes a ratio, not an absolute dollar amount. It has become commonplace for normative expositions of ROI in the management accounting literature (e.g. Anthony \& Govindarajan, 2007; Horngren, Datar, \& Foster, 2007) and the hospitality management accounting literature (e.g. Guilding, 2009) to demonstrate how ROI can be dissected into two underlying components: profit margin (profit $\div$ sales) and sales turnover (sales $\div$ assets). It is evident that there is some convergence between the profit margin element of ROI and conventional hotel operator incentives, due to the latter's emphasis on sales and profit. The element that is completely lacking, however, is the incentive to maximise sales for a given level of investment, as conventional operator incentives lack a measure that taps into the investment construct. RI is calculated as profit minus an imputed charge for capital employed. The imputed charge is generally linked to the cost of capital (Langfield-Smith, et al., 2003).

The major benefit of ROI is that the agent is discouraged from excessive investment in assets. ${ }^{7}$ Further advantages of ROI include: (1) it reflects anything that affects the financial statements; (2) it is easy to calculate, simple to understand, and is meaningful in an absolute sense; (3) it can be applied to any unit within an organisation responsible for profitability, regardless of the size or type of the business; and (4) as ROI data is typically available for competitors, it can be used as a basis for comparison (Anthony \& Govindarajan, 2007). ${ }^{8}$ A

\footnotetext{
${ }^{7}$ The merit of ROI is apparent from the following comment provided in a lodging sector company's 10-K Report: "Return on invested capital is a key profitability measure that provides an indication of the long-term health of our concepts. This metric is based on a comparison of operating profit to the average capital invested in our restaurants. We believe return on invested capital is a critical indicator in evaluating our ability to create long-term value for our shareholders.”(P.F. Chang's China Bistro Inc, 2008, p. 21).

8 Attempting cross company ROI comparisons is not straight forward, however, as the useful lives of depreciable assets will differ across hotels. As assets become fully depreciated, the measure of investment declines and ROI increases, undermining the merit of attempting cross hotel ROI comparisons.
} 
major disadvantage of ROI is that it can encourage agents to defer asset replacement and also discourage agents from investing in some capital projects that are viable from an owner's perspective, as will be seen below (this is sometimes referred to as an "underinvestment problem”). A second disadvantage is that managers evaluated on the basis of ROI may be dissuaded from investing in some positive NPV projects. This is because such projects may have low levels of profit and ROI in the early years of their useful lives. Consistent with most other accounting measures, a third disadvantage of ROI is that it does not represent an economic rate of return on capital, because accounting profit excludes many value increases such as land appreciation prior to sale, as well as intangible asset growth such as increases in brand value.

RI has been widely promoted as a measure that averts some of ROI's shortcomings (see Anthony \& Govindarajan, 2007; Christensen, Feltham, \& Wu, 2002; Dutta \& Reichelstein, 2002; Langfield-Smith, et al., 2003). RI’s improvement over ROI stems from its formula containing an important piece of data that is absent from the ROI formula, ie, the organisation's required rate of return on invested capital (Langfield-Smith, et al., 2003). ${ }^{9}$ Despite the theoretical strength of RI, Drury, Braund, Osborne, and Tayles (1993) note that surveys (e.g. Reece \& Cool, 1978; Scapens, Sale, \& Tikkas, 1982; Skinner, 1990) have indicated that practitioners show a strong preference for ROI because: (1) as a ratio, it can be used for comparisons within or between divisions; (2) ROI can be compared with other organisations or within an organisations' divisions; and (3) ROI is generally considered a measure of overall profitability and is therefore used more by outsiders.

\footnotetext{
${ }^{9}$ A hotel's required rate of return on invested capital is its cost of capital. In a hospitality management context Guilding (2009, p. 297) notes "the cost of capital is the average cost (stated as a percentage) of the capital funds raised by a company”. Viewed slightly differently, it is the rate of return that a company must earn in order for its market value to remain unchanged (assuming a steady stock market).
} 
In a hotel management investment decision making context, Guilding (2009, pp. 177-178) demonstrates how RI represents a preferred incentive basis to ROI. The case he depicts is reproduced as Table 6. The top panel provides the current scenario of a hotel chain with two hotels: Hotel A generating a 4\% ROI and -\$30,000 RI, and Hotel B generating an 18\% ROI and \$40,000 RI. The hotel chain is seeking a 10\% target ROI. Options that have arisen for the two hotels are outlined in the table's second panel and the ROI impact of acting on these options is outlined in the third panel. Hotel A has an incentive to purchase an asset costing $\$ 200,000$ as it would increase its ROI from $4 \%$ to $5.4 \%(\$ 38,000 \div \$ 700,000$ X 100). Hotel B has an incentive to sell an asset that generates $\$ 21,600$ for its $\$ 180,000$ book value, as the hotel's ROI would increase from $18 \%$ to $21.4 \%(\$ 68,400 \div \$ 320,000 \mathrm{X} 100)$. The flaw in the ROI incentive becomes apparent when it is recognised that the hotel chain is preparing to buy an asset that will earn a $9 \%$ ROI $(\$ 18,000 \div \$ 200,000)$ while at the same time selling a second asset earning a higher ROI of $12 \%(\$ 21,600 \div \$ 180,000)$. This problem is averted if RI maximisation is adopted as the performance measurement criterion. As is evident from Table 6’s final panel, if Hotel A were to make the $\$ 200,000$ asset purchase, its RI would drop from $-\$ 30,000(\$ 20,000-(0.1 X \$ 500,000))$ to $-\$ 32,000(\$ 38,000-(0.1 X \$ 700,000))$. If Hotel B were to make the $\$ 180,000$ asset sale, its RI would drop from $\$ 40,000$ (\$90,000 $(0.1 \mathrm{X} \$ 500,000))$ to $\$ 36,400(\$ 68,400-(0.1 \mathrm{X} \$ 320,000))$. The decline in the two hotels' respective RIs signify that neither should make the asset changes under consideration. 
When applying the RI algorithm, any investment that exceeds an organisation's required rate of return yields a positive RI. As a result, RI motivates managers to maximise profits from the resources that they have at their disposal and to only invest in additional resources when the investment will produce an adequate return (Anthony \& Govindarajan, 2007). Appendix A presents a simulated exercise that demonstrates how RI represents a performance measurement basis that promotes a higher degree of owner-operator capital expenditure goal congruency compared to traditional hotel operator fee bases that are tied to revenue and profit.

It was noted above that finance practice holds that the preferred investment appraisal criterion is NPV. It is noteworthy, therefore, to recognise that RI, considered over the long term, approximates to NPV. Using RI to evaluate management performance can be expected to promote goal congruency, because the information that is required for NPV and IRR converges (considered over the long term, accruals based differences between cash flows used in NPV calculations, and profit which is used in RI calculations, disappear). We can thus conclude that maximizing RI over time approximates to maximizing firm value.

Analysis of hotel management contracts in the U.S. provides some support for the view that RI represents a preferred basis for determining hotel operator remuneration. Eyster’s (1993) study cites examples of contracts where the basis for the remuneration fee is GOP (or cash flow) adjusted for items such as debt service and return on equity. Adjusting profit for debt service can be seen as a 'partial RI' measure, for although it embodies a charge for debt capital, no charge is made for equity funding. For the 5.9\% of contracts examined by Eyster where the operator remuneration is based on cash flow after debt service and return on equity, we have a closer approximation to RI. This is because the measure involves a charge made 
for all long-term capital funding (i.e. equity and debt). While this signifies the existence of some management contracts promoting a better alignment of owner-operator capital expenditure interests, this improved alignment will be largely negated if this type of incentive fee is combined with a base fee determined by gross revenue (the most common base fee noted in Table 2). More recent hotel management contract surveys (e.g. Barge \& Jacobs, 2001; Goddard \& Standish-Wilkinson, 2002; Haast, et al., 2005; K. Johnson, 1999; Panvisavas \& Taylor, 2006)have failed to identify any incentive fees tied to cash flow after debt service and return on equity.

With respect to the adoption of RI as a generic performance measure, Balachandran (2006) conducted an analysis of Compustat firms' RI usage. Table 7 provides an industry sector classification of Balachandran's RI adoption findings. The proportion of firms using RI measures ranged from $34.8 \%$ of durable goods firms to $0 \%$ of real estate firms. Considered holistically, these findings suggest limited application of RI across a range of industrial settings.

\section{INSERT TABLE 7 ABOUT HERE}

Although this study promotes using RI as a basis for determining operator fees, it should be noted that it is not devoid of shortcomings. RI is a financially denominated measure that is calculated from accrual accounting numbers. Performance measures that are based on accounting numbers are widely criticised for instilling a short-termist outlook (Ezzamel, 1992; Ezzamel \& Hart, 1989; Rappaport, 1986). In light of this, many commentators suggest combining financial and non-financial performance measures in an attempt to better align the interests of principals and agents (Aggarwal, 1991; Kakati \& Dhar, 1991; Slagmulder \& 
Bruggeman, 1992). ${ }^{10}$ If attempting to use RI in a cross hotel comparison, it must be recognised that it is an absolute number, and larger hotels would be expected to generate a higher residual income than smaller hotels, although this problem can be circumvented by using a hybrid measure that sees RI divided by assets employed. Consistent with other accounting based measures, RI measures performance within a one year window. This year's measure does not capture impacts occurring in subsequent years that stem from actions taken this year. For example, reducing maintenance or marketing to achieve a target profit may increase the current period's RI, but jeopardise future hotel value.

A further shortcoming of using ROI or RI relates to Healy's (1985) bonus plan hypothesis. Healy (1985) explains how the remuneration conditions existing between a principal and agent can cause the agent to make profit increasing or decreasing accounting policy choices. If ROI or RI is used to incentivise an operator, and profit in a particular year is negative, the operator may be induced to 'take a bath' by selectively expensing any potential future capital expenditure in the current period, to reduce capital charges assigned to future years. Given the high asset base associated with hotels, there appears to be considerable scope to manipulate the period in which substantial expenses are charged. Generally Accepted Accounting Principles (GAAP) and hotel management contracts provide little guidance resolving the issue concerning which asset related expenditures are to be expensed or capitalised (Schmidgall, Damitio, \& Singh, 1997). Research examining Healy’s (1985) hypothesis provides equivocal results, however. Studies supporting Healy's hypothesis include (see Bernard \& Skinner, 1996; Dechow, Sloan, \& Sweeney, 1995; Holthausen, Larcher, \& Sloan, 1995; J. Jones, 1991; Kaplan, 1985; McNichols \& Wilson, 1988; Schipper,

\footnotetext{
${ }^{10}$ Non-financial performance measures, for example, can include market share (Morishima, 1982; Prestowitz, 1988; Tsuruni, 1984; Van Wolferen, 1989); innovativeness (Goldsmith \& Clutterbuck, 1984); market standing (Saunders \& Wong, 1985); efficiency / productivity, product quality, customer satisfaction, employee satisfaction (Ittner, et al., 1997), and others.
} 
1989). Research providing conflicting evidence includes (see DeFond \& Park, 1997; Gaver, Gaver, \& Austin, 1995).

While the discussion in this section has been conducted in the context of seeking improved bases of hotel operator fee determination, it is also pertinent to identify appropriate performance measure thresholds that can be invoked by an owner as grounds for contract termination. Based on the rationale outlined, it would appear to be in owners' interests to require operators to meet performance thresholds stated in terms of ROI or RI.

\section{CONCLUSION AND DISCUSSION}

In any discussion of accounting measures that can be used as a basis of hotel operator fee determination, it is important to recognise the role that operator brand standards can play in hotel capital expenditure decision making (Beals \& Denton, 2005; Haast, et al., 2006; Schiff, 2006). If an owner deems a particular capital expenditure proposal to be unjustifiable on financial criteria grounds, but the operator sees the expenditure as necessary to meet their brand standard, if the owner rejects the proposal, the operator may have the right to terminate the contract (Beals \& Denton, 2005). In such a situation, although use of ROI or RI might suggest that the operator's capital expenditure interest is well aligned to the owner's interest, there is a strong brand standard factor at play that affects the operator's capital expenditure perspective. Although a proposed expenditure may have a negative ROI or RI (thereby potentially reducing an operator's incentive management fee), the operator may still support the expenditure if the benefit to their brand value outweighs any potential management fee reduction. 
This paper has demonstrated that widely used clauses in hotel management contracts provide an incentive for hotel operators to take actions consistent with maximising sales and profits, but not maximising return on investment. As the hotel management contract is ubiquitous in the Western World, this propensity to make management decisions on the criteria of maximising sales and profits without due regard given to capital employed can be expected to be a systemic feature of Western World hotel management. This signifies a potential systemic misallocation of effort and resources in the international hotel sector on a mass scale and appears worthy of further academic enquiry. From a practitioner perspective, the paper can be expected to be of particular interest to hotel owner groups such as the Asian American Hotel Owners Association, which has been active in furthering owner's interests through activities such as promotion of the fair franchising initiative. ${ }^{11}$

A potential line of research enquiry extending the current study's focus could examine the nature of a General Manager's engagement in hotels operating with a management contract. It is usual for the operator to engage the General Manager (Eyster, 1997; Guilding, 2003, 2006; Rushmore, 2002). In most cases, however, this appointment requires the approval of the owner (Guilding, 2003; Haast, et al., 2005). It is noteworthy that in some situations the owner pays for the General Manager's salary immediately (Dickson \& Williams, 2006), while in other situations the salary is initially paid for by the operator but is eventually reimbursed by the hotel owner (Eyster, 1997; Guilding, 2003). Regardless of which method is adopted, the owner's financing of the General Manager's salary continues throughout the entire term of the management contract. In some management contracts, the owner also has the authority to remove the General Manager for unacceptable performance (Crandell, Dickinson, \& Kanter, 2004). Clearly, such an employment arrangement gives rise to conflict

\footnotetext{
${ }^{11}$ Further information can be found at: http://www.aahoa.com
} 
because it detracts from the operator's degree of control over the General Manager, i.e., the General Manager feels accountable to the owner as well as the operator. Given the key role a General Manager plays in capital budget formulation (Rushmore, 2002), understanding the relative motivations of General Managers and the way they manage tensions between owners and operators would likely sharpen our appreciation of the dynamics at play in hotel capital budgeting. Should research be made of performance related pay of General Managers, it would be useful to determine if hotels are effective in distinguishing between the performance of a manager and the performance of a hotel, as a hotel may be a poor performer that is affected by economic conditions beyond a manager's control.

Further research could also examine factors arising from the growing incidence of owner engagement of asset managers to monitor operators (Armitstead, 2004; Bader \& Lababedi, 2007; Geller, 2002). This development appears to parallel growing owner realisation of inconsistencies between owner and operator interests (Feldman, 1995; Johnstone \& Duni, 1995). Although asset manager engagement is designed to promote improved owner-operator interest alignment (Bader \& Lababedi, 2007), it is notable that asset managers are traditionally recruited from the ranks of hotel management companies, where they have been previously employed as General Managers or Vice Presidents. As a result, asset managers’ often focus on short-term operational issues rather than building long-term value (Bridge \& Haast, 2004). Field study research into issues surrounding the degree to which asset managers promote owner-operator goal congruency has the potential to provide profound insights into the mechanics of hotel capital expenditure management.

Research could also be directed towards determining the extent to which hotel owners are requiring operators to take an equity stake in the ownership of the properties that they 
manage, as a mechanism to promote greater owner-operator goal congruency. An examination of the extent to which this represents a viable and productive means for promoting increased owner-operator goal congruency would provide a useful contribution to our understanding of the likely evolution of owner-operator contracting. 


\begin{tabular}{|c|c|c|c|}
\hline \multicolumn{4}{|c|}{$\begin{array}{c}\text { TABLE 1 } \\
\text { Percentage distribution of hotel operating modal types by major geographical } \\
\text { region }\end{array}$} \\
\hline Modal choice & North America & Europe & Asia \\
\hline Owner-operator (fully owned) & 9.46 & 28.60 & 22.40 \\
\hline $\begin{array}{c}\text { Owner-operator (partially owned, e.g. } \\
\text { joint venture) }\end{array}$ & 11.46 & 6.20 & 22.93 \\
\hline Franchise agreement & 38.31 & 28.66 & 12.45 \\
\hline Management contract & 40.76 & 36.53 & 42.21 \\
\hline Adapted from: Contractor and Kundu (1998) & & \\
\hline
\end{tabular}




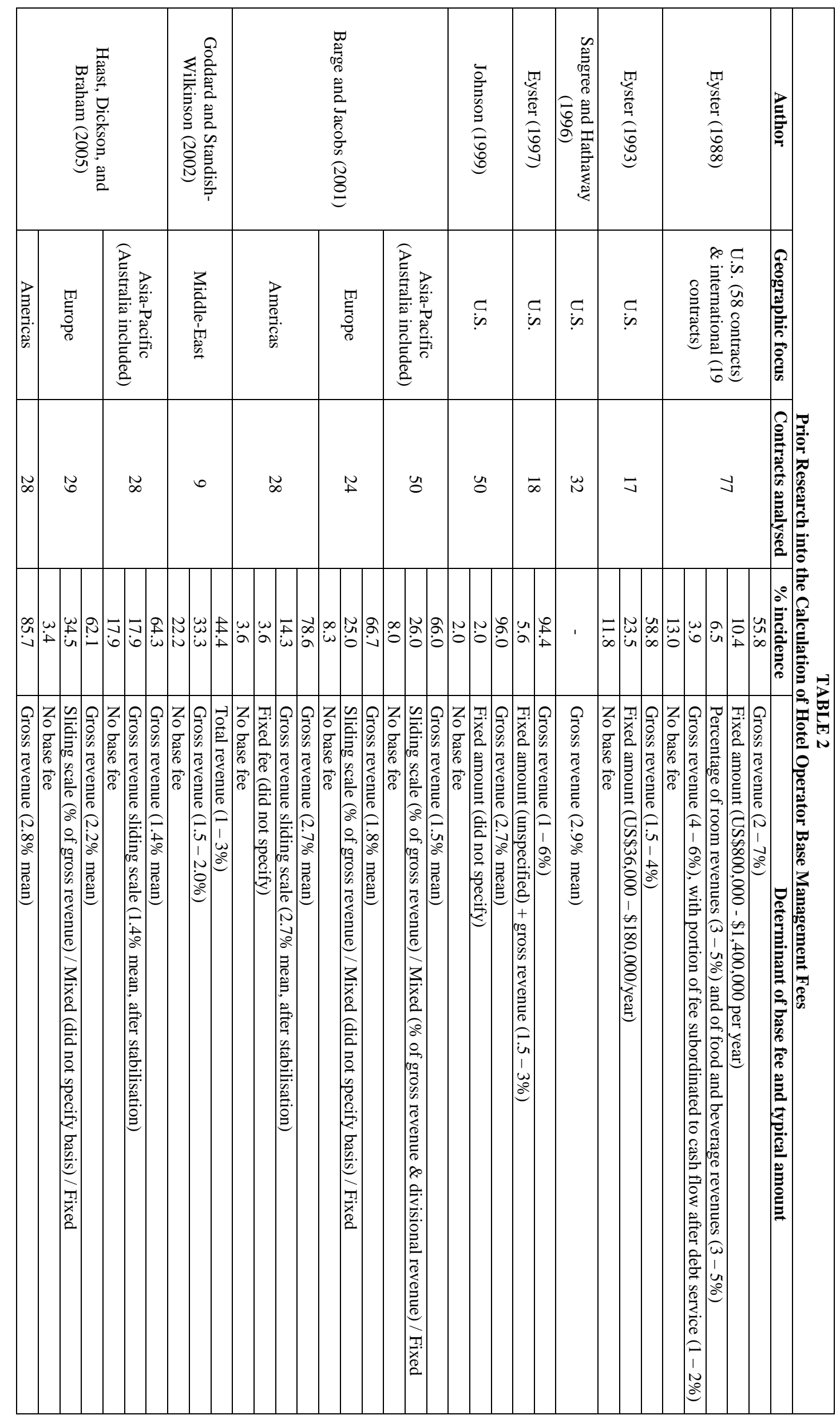




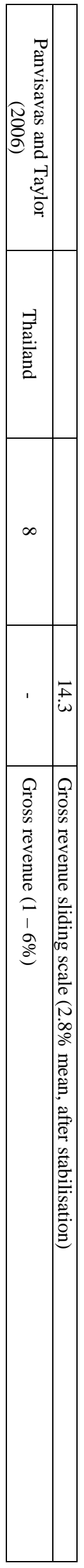




\begin{tabular}{|c|c|c|c|c|c|c|c|c|c|c|c|c|c|c|c|c|c|c|c|c|c|c|}
\hline 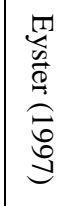 & \multicolumn{6}{|c|}{ 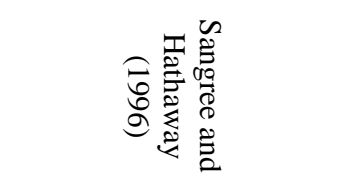 } & \multicolumn{5}{|c|}{ 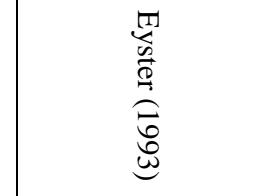 } & \multicolumn{8}{|c|}{ 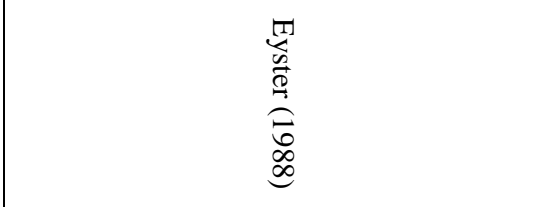 } & & & \\
\hline is & \multicolumn{6}{|c|}{ is } & \multicolumn{5}{|c|}{ is } & \multicolumn{8}{|c|}{ 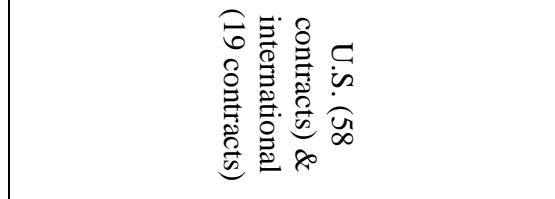 } & कृ & & \\
\hline$\vec{\infty}$ & \multicolumn{6}{|c|}{$\underset{N}{\omega}$} & \multicolumn{5}{|c|}{$\vec{v}$} & \multicolumn{8}{|c|}{$\checkmark$} & & & \\
\hline & 思 & 思 & 盌 & 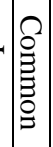 & & $\begin{array}{l}3 \\
0 \\
0 \\
6\end{array}$ & & & & & & 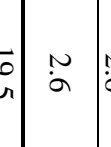 & ấ & טֶ) & $\stackrel{\sim}{\mathrm{N}}$ & 泉 & $\dot{a r}$ & & $\vec{D}$ & & & ד. \\
\hline 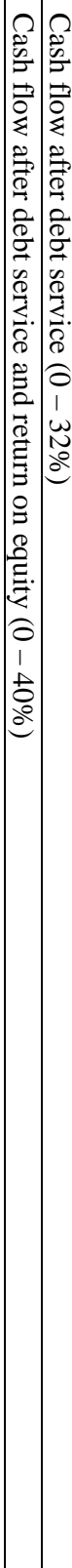 & 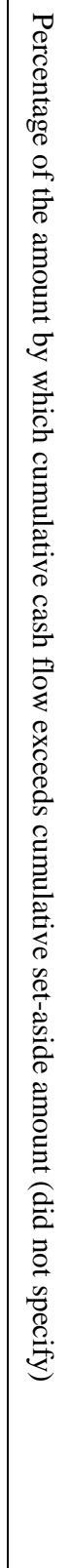 & 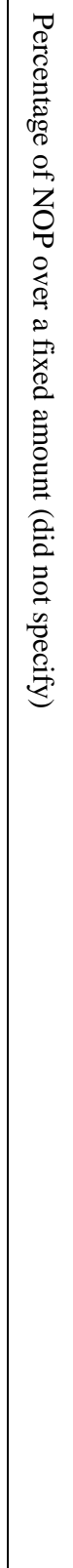 & 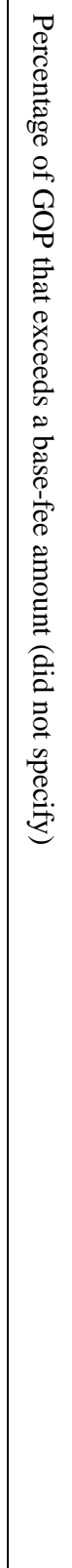 & 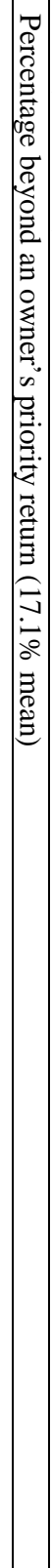 & 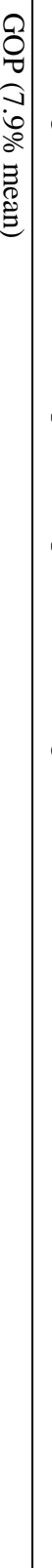 & 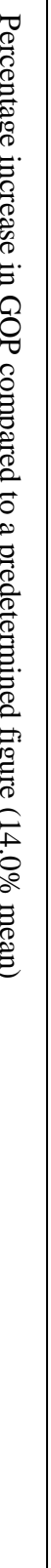 & 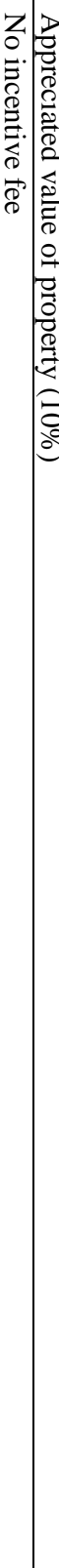 & 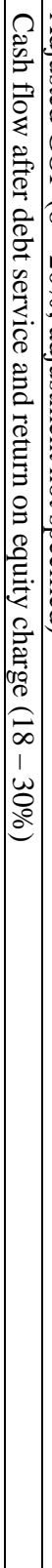 & 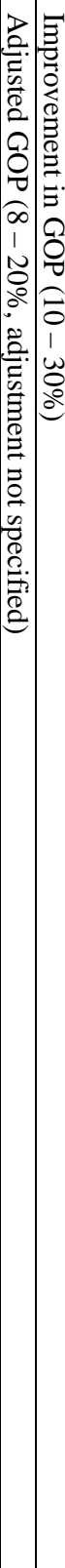 & 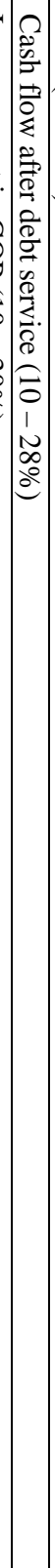 & 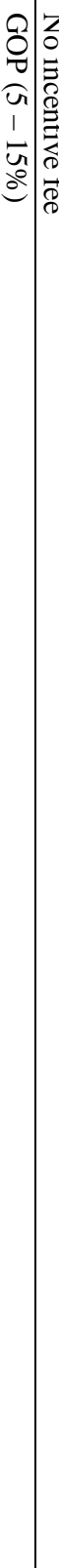 & 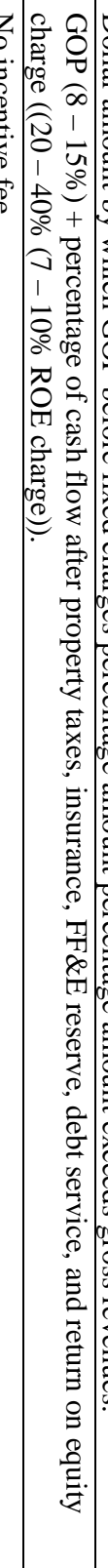 & 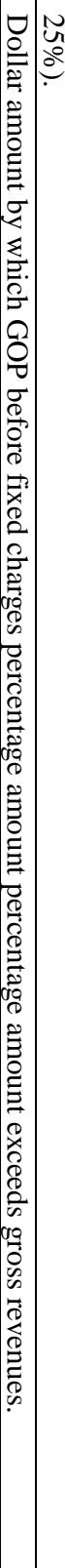 & 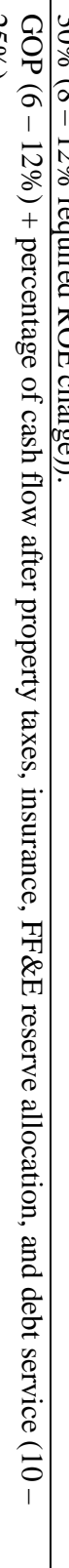 & 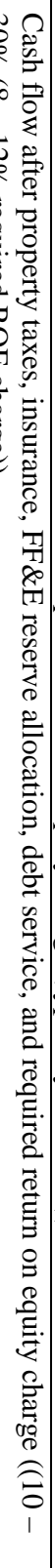 & 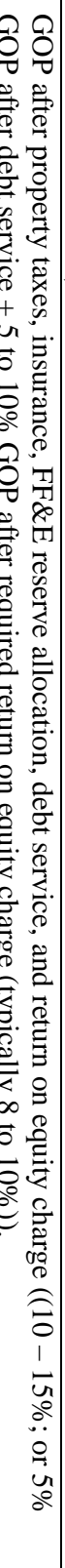 & 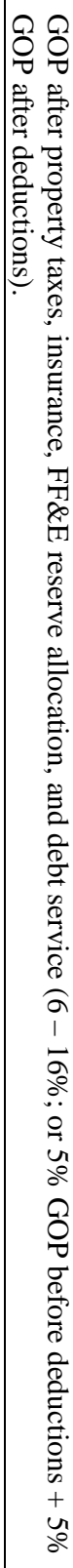 & 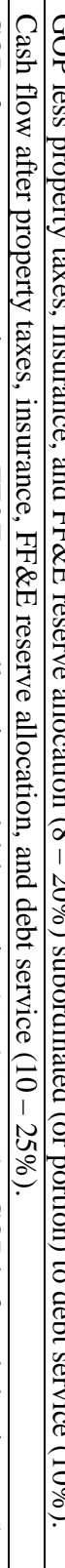 & 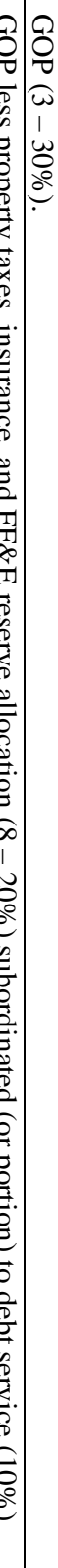 & & $\begin{array}{l} \\
\\
\\
\\
\end{array}$ & 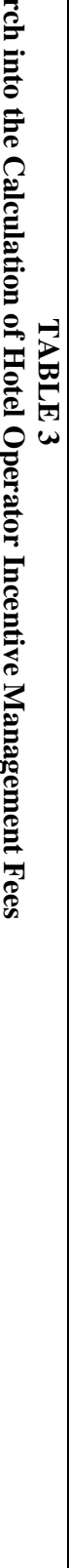 \\
\hline
\end{tabular}




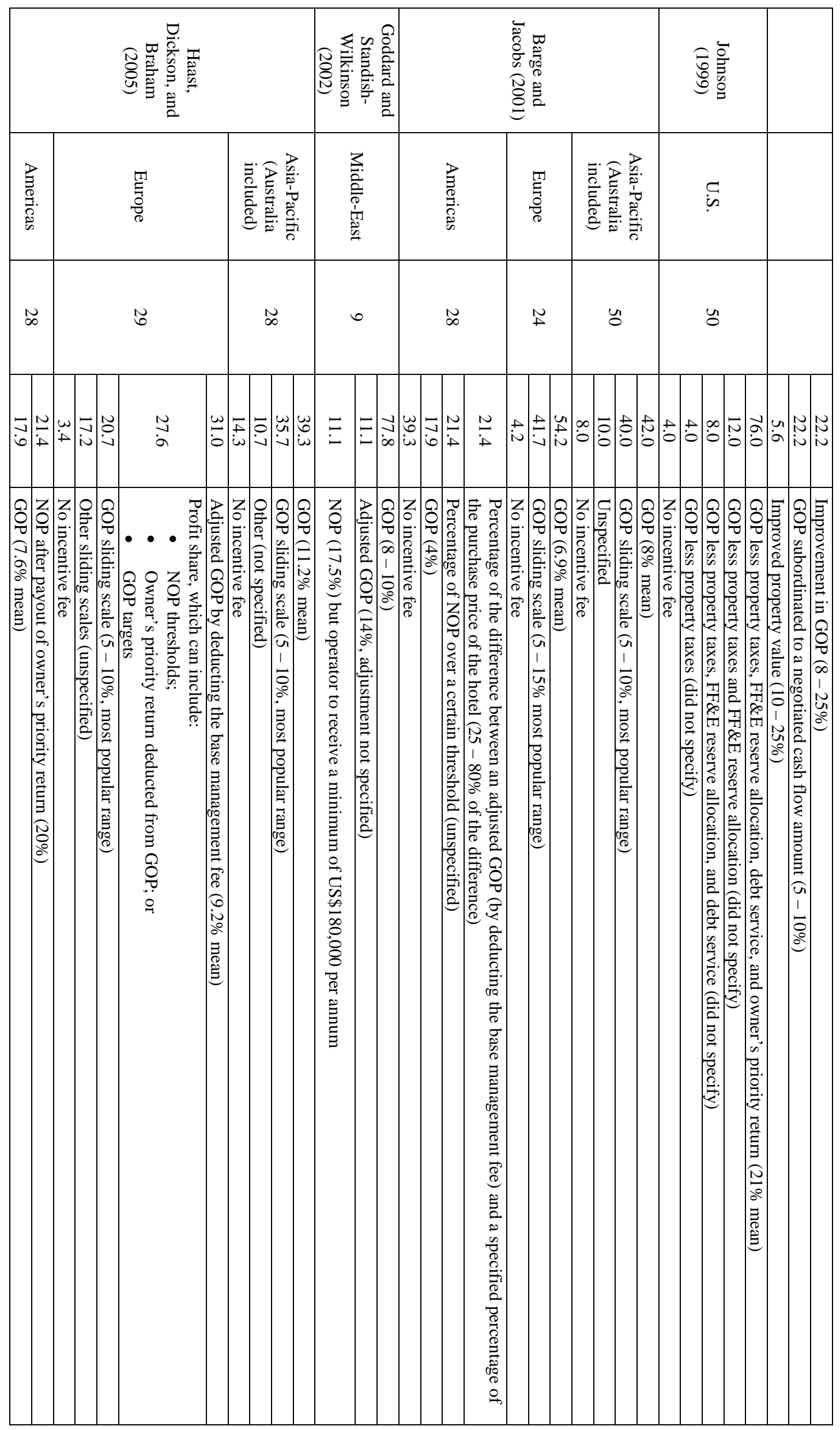




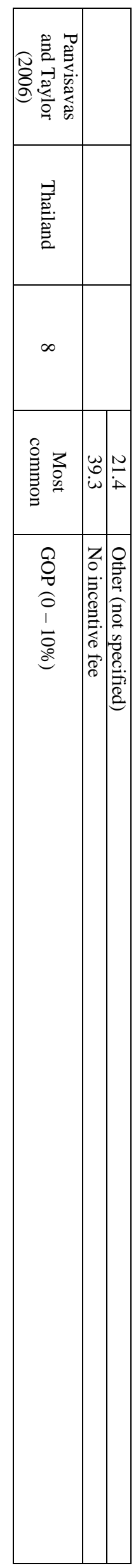




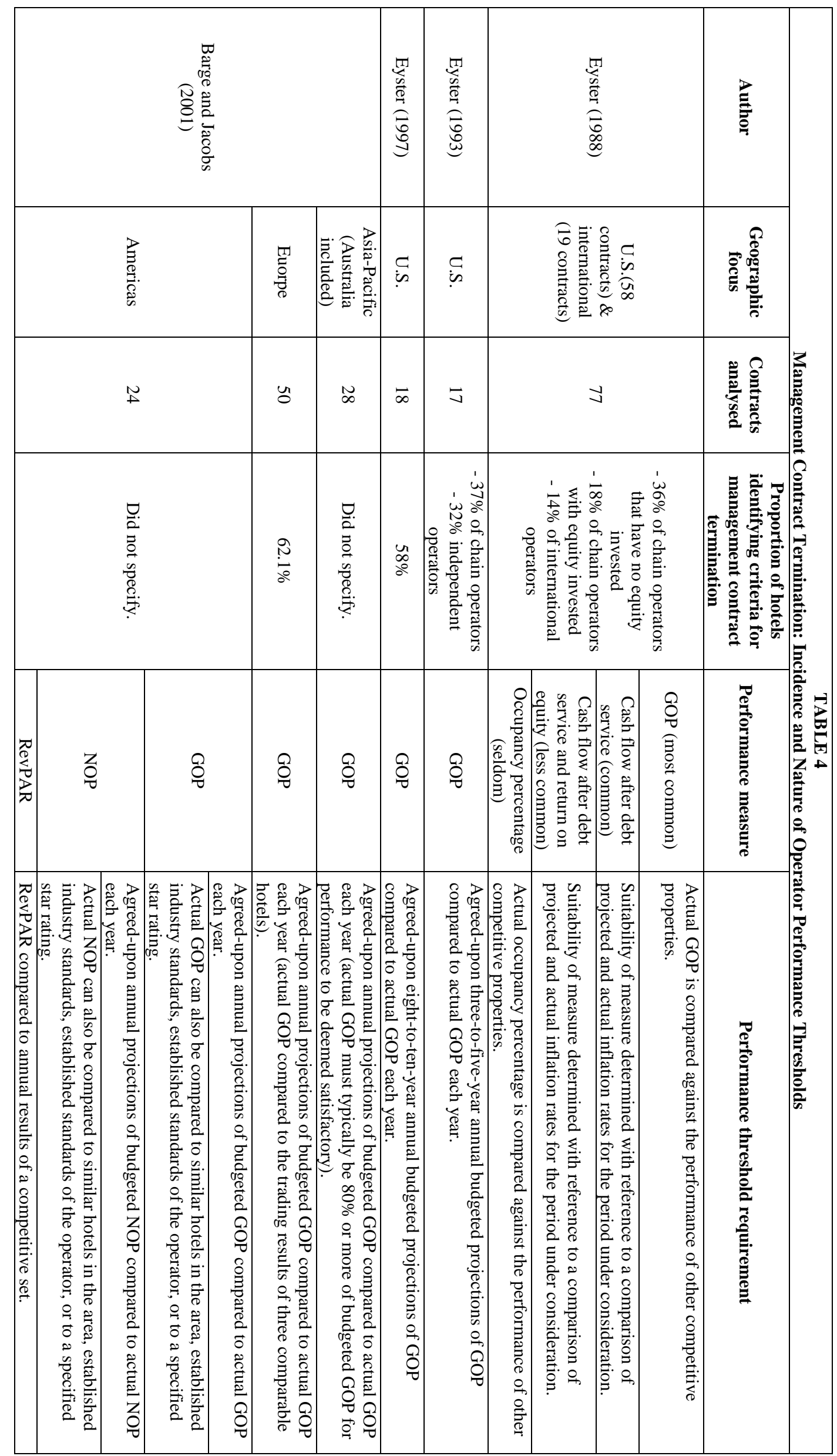




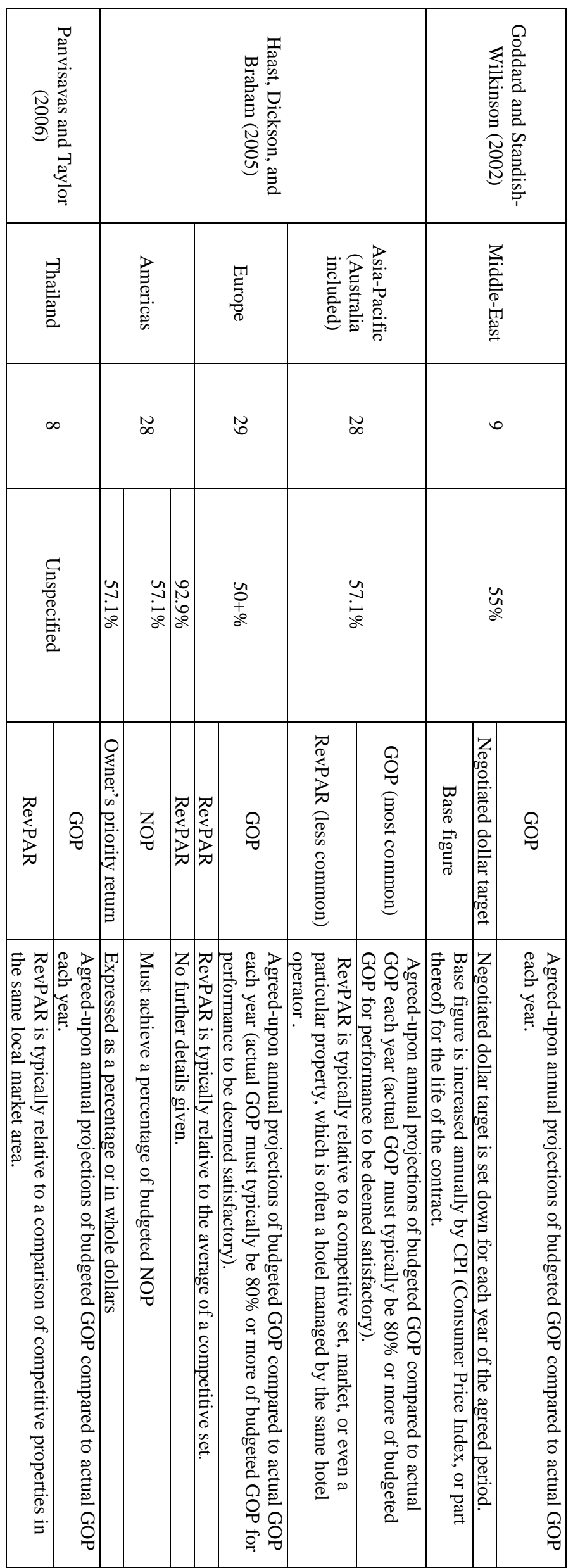




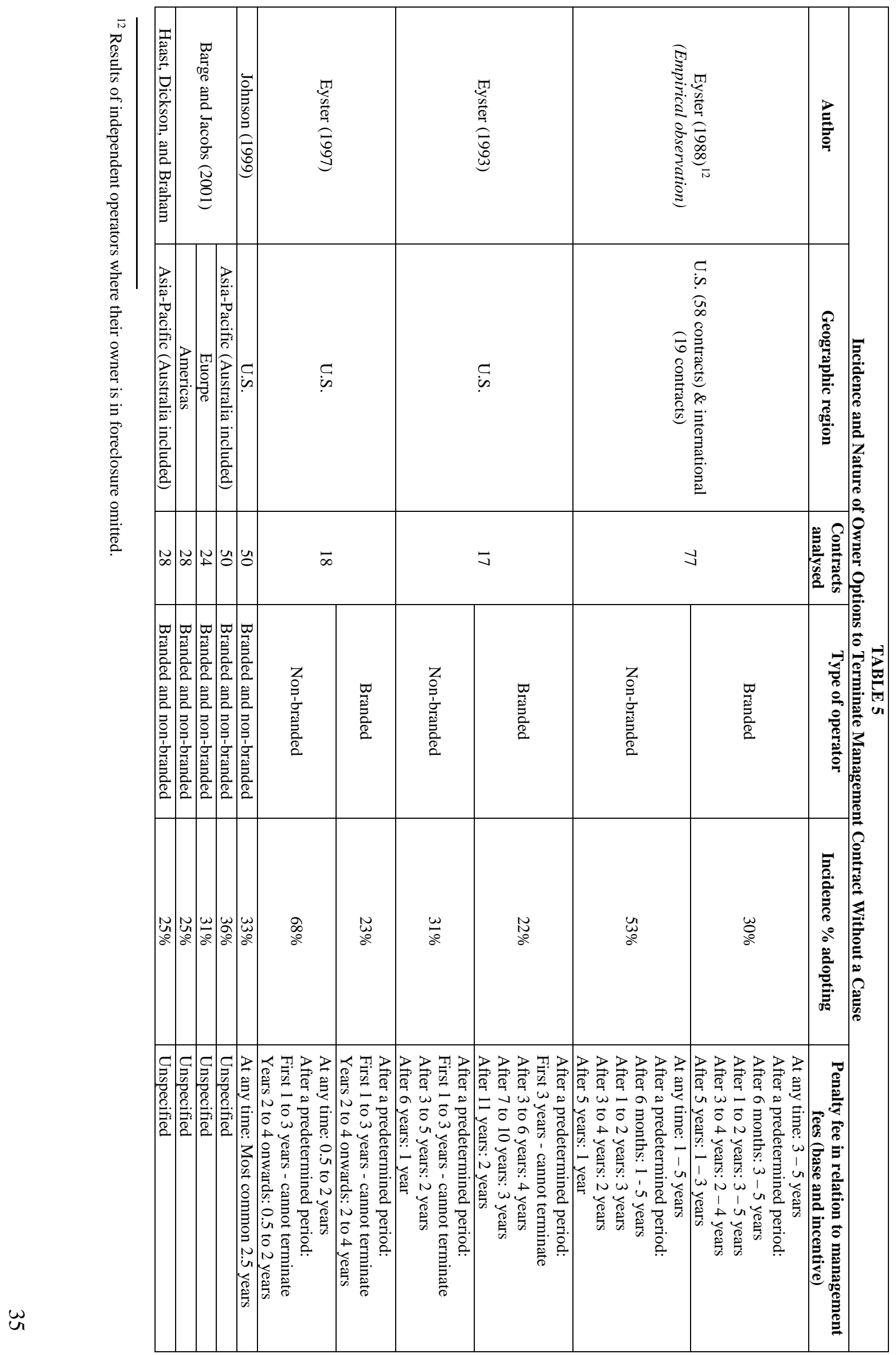




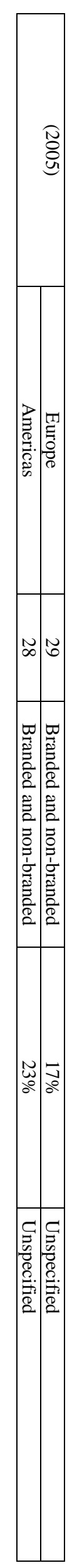




\section{TABLE 6}

Illustration of the merit of RI vs ROI

\begin{tabular}{|lrr|}
\hline Current scenario: & Hotel A & Hotel B \\
Investment in assets & $\$ 500,000$ & $\$ 500,000$ \\
Operating profit & $\$ 20,000$ & $\$ 90,000$ \\
ROI (Profit $\div$ Assets) & $4 \%$ & $18 \%$ \\
RI ((Profit - (Cost of capital X Assets)) & $-\$ 30,000$ & $\$ 40,000$ \\
\hline & & \\
Additional opportunity: & $\$ 200,000$ & \\
Purchase asset & & \\
Sell asset & $\$ 18,000$ & $-\$ 21,600$ \\
Change in profit & $9 \%$ & $12 \%$ \\
ROI associated with asset purchase or sale & & \\
\hline & & \\
ROI subsequent to asset purchase or sale: & $\$ 700,000$ & $\$ 320,000$ \\
Assets & $\$ 38,000$ & $\$ 68,400$ \\
Operating profit & $5.4 \%$ & $21.4 \%$ \\
New ROI & & \\
\hline & & \\
RI subsequent to asset purchase or sale: & $\$ 700,000$ & $\$ 320,000$ \\
Assets & $\$ 38,000$ & $\$ 68,400$ \\
Operating profit & $-\$ 32,000$ & $\$ 36,400$ \\
RI &
\end{tabular}




\begin{tabular}{|c|c|c|c|}
\hline \multicolumn{4}{|c|}{$\begin{array}{c}\text { TABLE } 7 \\
\text { RI adoption by industry }\end{array}$} \\
\hline Industry & $\begin{array}{c}\text { Number of } \\
\text { implementers }\end{array}$ & $\begin{array}{l}\text { Percent of } \\
\text { sample }\end{array}$ & $\begin{array}{l}\text { Average percent } \\
\text { of Compustat } \\
\text { firms }\end{array}$ \\
\hline $\begin{array}{l}\text { Mining and } \\
\text { construction }\end{array}$ & 6 & 3.2 & 7.7 \\
\hline Food & 7 & 3.8 & 2.3 \\
\hline $\begin{array}{l}\text { Textiles, printing, } \\
\text { publishing }\end{array}$ & 19 & 10.8 & 5.1 \\
\hline Chemicals & 7 & 3.8 & 1.8 \\
\hline Pharmaceuticals & 4 & 2.7 & 2.8 \\
\hline Extractive industries & 3 & 1.6 & 0.5 \\
\hline Durable goods & 63 & 34.8 & 20.1 \\
\hline Computers & 3 & 1.6 & 9.8 \\
\hline Transportation & 10 & 5.4 & 5.7 \\
\hline Utilities & 17 & 9.7 & 2.4 \\
\hline Retail & 18 & 9.7 & 10.9 \\
\hline $\begin{array}{l}\text { Financial } \\
\text { institutions }\end{array}$ & 10 & 5.4 & 11.5 \\
\hline Real estate & 0 & 0.0 & 8.5 \\
\hline Service & 13 & 7.0 & 9.8 \\
\hline Other & 1 & 0.5 & 1.1 \\
\hline Total & 181 & $100 \%$ & $100 \%$ \\
\hline
\end{tabular}




\section{Appendix A \\ Simulation of operator management fees: Comparison of traditional management fee basis with residual income fee basis}

Imagine a hotel operator is considering which of two mutually exclusive potential investment opportunities, Project A or Project B, it will promote to the owner of a hotel it manages. Project A will require an initial investment of $\$ 1,000,000$ and Project B will require an initial investment of $\$ 4,000,000$. The projected revenue and profit projections associated with the two investment alternatives are outlined below.

\begin{tabular}{|c|c|c|c|c|}
\hline & \multicolumn{2}{|c|}{ Project A } & \multicolumn{2}{c|}{ Project B } \\
\hline & Revenue & Gross operating profit & Revenue & Gross operating profit \\
\hline Year 1 & $\$ 500,000$ & $\$ 200,000$ & $\$ 800,000$ & $\$ 320,000$ \\
\hline Year 2 & $\$ 500,000$ & $\$ 200,000$ & $\$ 800,000$ & $\$ 320,000$ \\
\hline Year 3 & $\$ 500,000$ & $\$ 200,000$ & $\$ 800,000$ & $\$ 320,000$ \\
\hline Year 4 & $\$ 500,000$ & $\$ 200,000$ & $\$ 800,000$ & $\$ 320,000$ \\
\hline Year 5 & $\$ 500,000$ & $\$ 200,000$ & $\$ 800,000$ & $\$ 320,000$ \\
\hline
\end{tabular}

Based on a typical traditional fee incentive of $3 \%$ of gross revenue and $10 \%$ of gross operating profit, we find that the operator would prefer Project B as it would result in an increase in the operator fee revenue of $\$ 56,000$ (3\% of $\$ 800,000+10 \%$ of $\$ 320,000)$ per annum for the five years of Project B's life. This is more than the $\$ 35,000$ (3\% of $\$ 500,000+10 \%$ of $\$ 200,000$ ) projected incremental fee revenue that would result if Project A were pursued.

On an ROI and RI basis, it can be seen than project A provides the higher return, however. Project A provides an ROI of $20 \%$ (\$200,000 $\div \$ 1,000,000$ X 100) per annum and Project B provides an ROI of $8 \%(\$ 320,000 \div \$ 4,000,000$ X 100) per annum. If the hotel owner imputes a $10 \%$ required rate of return (based on its cost of capital) charge when calculating RI, we see that Project A has a positive RI of $\$ 100,000(\$ 200,000-(0.1 \times \$ 1,000,000))$ per annum and Project B has a negative RI of $\$ 80,000(\$ 320,000-(0.1 X \$ 4,000,000))$ per annum.

If the operator were to be paid an incentive that is set at (say) $40 \%$ of RI, pursuit of Project A would result in an increase in the operator's fee revenue of $\$ 40,000$ (40\% of $\$ 100,000)$ per annum and pursuit of Project B would result in a decrease in the operator's fee revenue of $\$ 32,000$ (40\% of $-\$ 80,000$ ) per annum.

A comparison of the projected ROIs for the two projects and the fact that Project B fails to satisfy the owner's $10 \%$ required rate of return provides a persuasive case that the hotel owner would prefer to take Project A. Capital expenditure goal congruency is promoted if the operator is remunerated based on RI (Project A has the higher RI), but it is not promoted if the operator is remunerated based on a revenue and profit incentive, as the operator would have an incentive to promote Project B. 


\section{References}

Aggarwal, R. (1991). Justifying investments in flexible manufacturing technology: Adding strategic analysis to capital budgeting under uncertainty. Managerial Finance, 17(2-3), 77-88.

Anthony, R., \& Govindarajan, V. (2007). Management control systems (12th ed.). New York, NY: McGraw-Hill Irwin.

Armitstead, M. (2004). Hotel management and operations options: Intellectual capital versus financial capital. Journal of Retail \& Leisure Property, 3(4), 299-307.

Armitstead, M., \& Marusic, M. (2006). Evaluating a deal in the hospitality industry. Journal of Retail \& Leisure Property, 5(3), 197-203.

Baber, W., Kang, S., \& Kumar, K. R. (1998). Accounting earnings and executive compensation: The role of earnings persistence. Journal of Accounting and Economics, 25, 169-193.

Bader, E. E., \& Lababedi, A. (2007). Hotel management contracts in Europe. Journal of Retail \& Leisure Property, 6(2), 171-179.

Baiman, S. (1990). Agency theory in managerial accounting: A second look. Accounting Organizations and Society, 15, 341-371.

Baiman, S., Evans, J. H., \& Noel, J. (1987). Optimal contracts with a utility maximising auditor. Journal of Accounting Research, 217-244.

Baker, G. P., Jensen, M., \& Murphy, K. J. (1988). Compensation and incentives: Practice vs. theory. Journal of Finance, 43(3), 593-616.

Balachandran, S. V. (2006). How does residual income affect investment? The role of prior performance measures. Management Science, 52(3), 383-394.

Barge, P., \& Jacobs, D. (2001). Management agreement trends worldwide, Hotel Topics (Vol. June, pp. 1-20): Jones Lang LaSalle Hotels.

Basu, A., Lai, R., Srinivasan, V., \& Staelin, R. (1985). Sales-force compensation plans: An agency theoretic perspective. Marketing Science, 4, 267-291.

Beals, P. (1995). The hotel management contract: lessons from the North American experience. In P. J. Harris (Ed.), Accounting and finance for the international hospitality industry. Oxford: Butterworth-Heinemann.

Beals, P., \& Denton, G. A. (2005). The current balance of power in North American hotel management contracts. Journal of Retail \& Leisure Property, 4(2), 129146. 
Beattie, R. (1991). Hospitality internationalization - an empirical investigation. International Journal of Contemporary Hospitality Management, 3(4), 14-24.

Berger, J. (1997). Applying performance tests in hotel management agreements. Cornell Hotel and Restaurant Administration Quarterly, 38(2), 25-32.

Berle, A., \& Means, G. (1962). The modern corporation and private property. New York: The Macmillan Company.

Bernard, V. L., \& Skinner, D. J. (1996). What motivates managers' choice of discretionary accruals? Journal of Accounting and Economics(AugustDecember), 313-325.

Biddle, G., Bowen, R. M., \& Wallace, J. (1997). Does EVA beat earnings? Evidence on associations with returns and firm values. Journal of Accounting and Economics, 24, 301-336.

Brander-Brown, J. (1995). Management control in the hospitality industry: Behavioural implications. In P. J. Harris (Ed.), Accounting and finance for the international hospitality industry. Oxford: Butterworth-Heinemann.

Bridge, D., \& Haast, A. (2004). Asset management. In J. Ransley \& H. Ingram (Eds.), Developing hospitality properties \& facilities (2nd ed.). Burlington, MA: Elsevier Butterworth-Heinemann.

Brooke, J., \& Denton, G. A. (2007). CapEx 2007: A study of capital expenditures in the hotel industry. Alexandria, VA.

Butler, R., Davis, L., Pike, R., \& Sharp, J. (1993). Strategic investment decisions: Theory, practice, and process. London: Routledge.

Chan, K. T., Lee, R. H. K., \& Burnett, J. (2001). Maintenance performance: A case study of hospitality engineering systems. Facilities, 19(13/14), 494-504.

Chen, S., \& Dodd, J. L. (1997). Usefulness of operating income, residual income, and $\mathrm{EVA}^{\mathrm{TM}}$ : A value-relevance perspective, working paper. Social Science Research Network.

Christensen, P., Feltham, G. A., \& Wu, M. (2002). Cost of capital in residual income for performance evaluation. The Accounting Review, 77(1), 1-23.

Collier, P., \& Gregory, A. (1995a). Investment appraisal in service industries: A field study analysis of the U.K. hotels sector. Management Accounting Research, 6(1), 33-57.

Collier, P., \& Gregory, A. (1995b). The practice of management accounting in hotel groups. In P. J. Harris (Ed.), Accounting and finance for the international hospitality industry. Oxford: Butterworth-Heinemann. 
Condon, D. T., Blaney, T., \& Harrington, D. J. (1996). How to finance capital expenditures: Capital spending decisions are a key to a club's future. The Bottom Line, 11(7), 6-7.

Contractor, F. J., \& Kundu, S. K. (1998). Modal choice in a world of alliances: Analyzing organizational forms in the international hotel sector. Journal of International Business Studies, 29(2), 325.

Corgel, J. (2007). Technological change as reflected in hotel property prices. The Journal of Real Estate Finance and Economics, 34(2), 257-279.

Cotter, J. F., \& Zenner, M. (1994). How managerial wealth affects the tender offer process. Journal of Financial Economics, 35, 63-97.

Crandell, C., Dickinson, K., \& Kanter, G. I. (2004). Negotiating the hotel management contract. In P. Beals \& G. A. Denton (Eds.), Hotel asset management: Principles \& Practices. East Lansing, MI: University of Denver and American Hotel \& Lodging Educational Institute.

Damitio, J. W., \& Schmidgall, R. S. (2002). Capital budgeting of major lodging chains. FIU Hospitality Review(Spring), 34-41.

Dave, U. (1984). US multinational involvement in the international hotel sector - an analysis. Services Industries Journal, 4, 48-63.

Dechow, P. M., \& Sloan, R. G. (1991). Executive incentives and the horizon problem: An empirical investigation. Journal of Accounting and Economics, 14, 51-89.

Dechow, P. M., Sloan, R. G., \& Sweeney, A. P. (1995). Detecting earnings management. Accounting Review(April), 193-225.

DeFond, M. L., \& Park, C. W. (1997). Smoothing income in anticipation of future earnings. Journal of Accounting and Economics, 115-139.

DeFranco, A. (1997). The importance and use of financial forecasting and budgeting at the department level as perceived by hotel controllers. Hospitality Research Journal, 20(3), 99-110.

Demski, J., \& Feltham, G. A. (1978). Economic incentives in budgetary control systems. The Accounting Review, 53(April), 336-359.

Dev, C. S., Morgan, M. S., \& Shoemaker, S. (1995). A positioning analysis of hotel brands - based on travel-manager perceptions. Cornell Hotel and Restaurant Administration Quarterly, 36(6), 48.

Dickson, G. (2007). Ten hot management agreement issues in Asia. Hotels Resorts \& Tourism Newsletter, June, 1-11. Retrieved from http://www.bakernet.com/NR/rdonlyres/86BE8EF9-2715-4591-86977E25966CFD58/42504/HRTNewsletterJuly2007.pdf 
Dickson, G., \& Williams, R. (2006). What's hot and what's not with management agreements? Hotels, resorts and tourism newsletter, (April), 1-10. Retrieved from http://www.bakernet.com/NR/rdonlyres/85BD956A-42E9-40E1-A5BA93A3F9E72D65/39800/SYDDMS388712v1HRT_Newsletter_April_2005final .pdf

Dimou, I., Chen, J., \& Archer, S. (2003). The choice between management contracts and franchise agreements in the corporate development of international hotel firms. Journal of Marketing Channels, 10(3,4), 33-39.

Drury, C., Braund, S., Osborne, P., \& Tayles, M. (1993). A survey of management accounting practices in UK manufacturing companies. London: Certified Accountants Educational Trust.

Dunning, J. H., \& McQween, M. (1981). The eclectic theory of multinational production: A case study of the international hotel industry. Managerial and Decision Economics, 2(4), 197-210.

Dutta, S. (2003). Capital budgeting and managerial compensation: Incentive and retention effects. The Accounting Review, 78(1), 71-94.

Dutta, S., \& Reichelstein, S. (2002). Controlling investment decisions: Depreciation and capital charges. Review of Accounting Studies, 7(2-3), 253-281.

Eder, R. W., \& Umbreit, W. T. (1987). Measures of management effectiveness in the hotel industry. Hospitality Education and Research Journal, 13(3), 333-341.

Eisenhardt, K. M. (1988). Agency and institutional explanations of compensation in retail sales. Academy of Management Journal, 488-511.

Eisenhardt, K. M. (1989). Agency theory: An assessment and review. Academy of Management Review, 14(1), 57-74.

Eyster, J. J. (1988). The negotiation and administration of hotel and restaurant management contracts (3rd ed.). Ithaca: School of Hotel Administration, Cornell University.

Eyster, J. J. (1993). The revolution in domestic hotel management contracts. Cornell Hotel and Restaurant Administration Quarterly, 34(1), 16.

Eyster, J. J. (1997). Hotel management contracts in the U.S.: Twelve areas of concern. Cornell Hotel and Restaurant Administration Quarterly, 38(3), 21-34.

Eyster, J. J., \& Geller, A. N. (1981). The capital investment decision: Techniques used in the hospitality industry. Cornell Hotel and Restaurant Administration Quarterly, 22(1), 69-73.

Ezzamel, M. (1992). Business unit and divisional performance measurement. London: Academic Press. 
Ezzamel, M., \& Hart, M. (1989). Advanced management accounting: An organisational emphasis. London: Cassell.

Feldman, D. S. (1995). Asset management: Here to stay. Cornell Hotel and Restaurant Administration Quarterly, 36(5), 36-52.

Ferguson, D. H., \& Selling, T. I. (1985). Probability analysis: A system for making better decisions. Cornell Hotel and Restaurant Administration Quarterly, 26(2), 35-43.

Field, H. M. (1995). Financial management implications of hotel management contracts: A UK perspective. In P. J. Harris (Ed.), Accounting and finance for the international hospitality industry. Oxford: Butterworth-Heinemann.

Fladmoe-Lindquist, K., \& Laurent, L. J. (1995). Control modes in international service operations: The propensity to franchise. Management Science, 41(7), 1238-1249.

Gannon, J., \& Johnson, K. (1997). Socialization control and market entry modes in the international hotel industry. International Journal of Contemporary Hospitality Management, 9(5/6), 193-209.

Garcia-Falcon, J. M., \& Medina-Munoz, D. (1999). The relationship between hotel companies and travel agencies: An empirical assessment of the United States market. The Service Industries Journal, 19(4), 102-123.

Gaver, J., Gaver, K., \& Austin, J. R. (1995). Additional evidence of bonus plans and income management. Journal of Accounting and Economics, 3-28.

Geller, L. (2002). The demands of globalization on the lodging industry. FIU Hospitality Review(Spring), 1-6.

Goddard, P., \& Standish-Wilkinson, G. (2002). Hotel management contract trends in the Middle East. Journal of Retail \& Leisure Property, 2(1), 66-71.

Goldsmith, W., \& Clutterbuck, D. (1984). The winning streak, Britain's top companies reveal their formulas for success. London: Weidenfield \& Nicolson.

Gross-Turner, S. (1999). The role of the multi-unit manager in branded hospitality chains. Human Resource Management Journal, 9(4), 39-57.

Guilding, C. (2003). Hotel owner/operator structures: Implications for capital budgeting process. Management Accounting Research, 14(3), 179-199.

Guilding, C. (2006). Investment appraisal issues arising in hotels governed by a management contract. In P. J. Harris \& M. Mongiello (Eds.), Accounting and financial management: Developments in the international hospitality industry (pp. 400 - 422). Oxford: Butterworth-Heinemann. 
Guilding, C. (2009). Accounting essentials for hospitality managers. Oxford: Butterworth Heinemann.

Guilding, C., \& Hargreaves, B. (2003). How hoteliers do their capital budgeting. Hospitality Review, 5(1), 45-49.

Guilding, C., Kennedy, D., \& McManus, L. (2001). Extending the boundaries of customer accounting: Applications in the hotel industry. Journal of Hospitality Tourism Research, 25(2), 173-194.

Guilding, C., \& Lamminmaki, D. (2007). Benchmarking hotel capital budgeting practices to practices applied in non-hotel companies. Journal of Hospitality and Tourism Research, 31(4), 486-503.

Haast, A., Adler, A., Wynne-Smith, M., Gibson, D., Nair-Grepinet, A., Ottevaere, J., et al. (2006). The hotel ownership pendulum in motion (pp. 1-40): Jones Lang LaSalle Hotels.

Haast, A., Dickson, G., \& Braham, D. (2005). Global hotel management agreement trends (Vol. June, pp. 1-24): Jones Lang LaSalle Hotels.

Haktanir, M., \& Harris, P. J. (2005). Performance measurement practice in an independent hotel context: A case study approach. International Journal of Contemporary Hospitality Management, 17(1), 39-50.

Harris, P. J., \& Mongiello, M. (2001). Key performance indicators in European hotel properties: General managers' choices and company profiles. International Journal of Contemporary Hospitality Management, 13(3), 120-127.

Hayes, D. K., \& Ninemeier, J. D. (2004). Hotel operations management. Upper Saddle River, NJ: Pearson Education.

Healy, P. M. (1985). The effect of bonus schemes on accounting decisions. Journal of Accounting and Economics, 7, 85-107.

Holthausen, R. W., Larcher, D. F., \& Sloan, R. G. (1995). Annual bonus schemes and the manipulation of earnings. Journal of Accounting and Economics(February), 29-74.

Horngren, C. T., Datar, S. M., \& Foster, G. (2007). Cost accounting: A managerial emphasis. Upper Saddle River, NJ: Prentice Hall.

Horwath (2006). Hotel, leisure and tourism - consulting services brochure. Horwath Asia Pacific.

Huszagh, S. M., Huszagh, F. W., \& McIntyre, F. S. (1992). International franchising in the context of competitive strategy and the theory of the firm. International Marketing Review, 9(5), 5-18. 
Ingram, P., \& Baum, J. (1997). Chain affiliation and the failure of Manhattan hotels, 1898-1980. Administrative Science Quarterly, 42(1), 68-103.

Ittner, C., Larker, D. F., \& Rajan, R. (1997). The choice of performance measures in annual bonus contracts. The Accounting Review, 72, 231-255.

Jagels, M. G. (2007). Hospitality management accounting (9th ed.). New Jersey: John Wiley and Sons.

Jensen, M., \& Meckling, W. (1976). Theory of the firm: Managerial behaviour, agency costs and ownership structure. Journal of Financial Economics, 3(October), 305-360.

Johnson, B. (1987). Discussion of management compensation contracts and mergerinduced abnormal returns. Journal of Accounting Research, 25(Supplement), 77-84.

Johnson, K. (1999). Hotel management contract terms: Still in flux. Cornell Hotel and Restaurant Administration Quarterly, 40(2), 34-40.

Johnstone, D. T., \& Duni, J. A. (1995). Asset management issues. In L. E. Raleigh \& R. J. Roginsky (Eds.), Hotel investments: Issues \& perspectives. East Lansing, MI: American Hotel \& Motel Association.

Jones, J. (1991). Earnings management during import relief investigations. Journal of Accounting Research(Autumn), 193-228.

Jones, P. (1996). Introduction to hospitality operations. London: Cassell.

Jones, T. (1998). UK hotel operators use of budgetary procedures. International Journal of Contemporary Hospitality Management, 10(3), 96.

Kakati, M., \& Dhar, U. R. (1991). Investment justification in flexible manufacturing systems. Engineering Costs and Production Economics, 21, 203-209.

Kaplan, R. S. (1985). Comments on Paul Healy. Journal of Accounting and Economics(April), 109-113.

Kedia, B. L., Ackerman, D., Bush, D. E., \& Justis, R. T. (1994). Determinants of internationalization of franchising operations by U.S. franchisors. International Marketing Review, 11(4), 56-68.

Langfield-Smith, K., Thorne, H., \& Hilton, R. W. (2003). Management accounting: An Australian perspective (3rd ed.). Roseville, Australia: McGraw-Hill.

Litteljohn, D. (1991). Towards an economic analysis of trans/multinational hotel companies. International Journal of Hospitality Management, 4(4), 157-165.

Litteljohn, D., \& Beattie, R. (1992). The European hotel industry: Corporate structures and expansion strategies. Tourism Management(March), 27-33. 
Lynch, B. (2002). Maximising FM's contribution to shareholder value part 1: Can the capital expenditure process for fixed assets be improved? Journal of Facilities Management, 1(1), 48-56.

Magee, R. P. (1980). Equilibria in budget participation. Journal of Accounting Research(Autumn), 551-573.

McNichols, M., \& Wilson, G. P. (1988). Evidence of earnings management from the provision for bad debts. Journal of Accounting Research(Supplement), 1-31.

Mellen, S., Nylen, K., \& Pastorino, R. (2000). Capex 2000: A study of capital expenditures in the U.S. hotel industry. Alexandria, VA.

Morishima, M. (1982). Why has Japan succeeded. Cambridge: Cambridge University Press.

Ohlson, J. A. (1995). Earnings, book value, and dividends in security valuation. Contemporary Accounting Research, 11(2), 661-687.

P.F. Chang's China Bistro Inc (2008). 10K-report.

Panvisavas, V., \& Taylor, J. S. (2006). The use of management contracts by international hotel firms in Thailand. International Journal of Contemporary Hospitality Management, 18(3), 231-245.

Payne, J. D., Carrington-Heath, W., \& Gale, L. R. (1999). Comparative financial practice in the US and Canada: Capital budgeting and risk assessment techniques. Financial Practice and Education, 9(1), 16-24.

Phillips, P. (2003). Capital expenditure in hotel chains: Implications for corporate structure. University of Surrey School of Management.

Prestowitz, C. V. (1988). Trading places. New York: Free Press.

Rainsford, P. (1994). Selecting and monitoring hotel-management companies. Cornell Hotel and Restaurant Administration Quarterly, 35(2), 30-35.

Ransley, J., \& Ingram, H. (2001). What is "good" hotel design? Facilities, 19(1/2), 79-90.

Rappaport, A. (1986). Creating shareholder value. New York: Free Press.

Reece, J. S., \& Cool, W. R. (1978). Measuring investment centre performance. Harvard Business Review(May-June), 29-49.

Reichardt, H. J., \& Lennhoff, D. C. (2003). Hotel asset allocation: Separating the tangible personality. Assessment Journal, 10(1), 25-32. 
Rushmore, S. (2002). Hotel investments handbook Available from http://www.hospitalitynet.org/news/4021216.search?query=chapter+20+hotel + management + contracts + pdf

Sangree, D. J., \& Hathaway, P. P. (1996). Trends in hotel management contracts. Cornell Hotel and Restaurant Administration Quarterly, 37(5), 26-38.

Saunders, J., \& Wong, V. (1985). In search of excellence in the UK. Journal of Marketing Management, 1(2), 119-137.

Scapens, R., W., Sale, J. T., \& Tikkas, P. A. (1982). Financial control of divisional capital investment. London: Institute of Cost and Management Accountants.

Schiff, C. (2006). What's next for better decision-making? DM Review, 16(12), 30-32.

Schipper, K. (1989). Commentary on earnings management. Accounting Horizons(December), 91-102.

Schlup, R. (2004). Hotel management agreements: Balancing the interests of owners and operators. Journal of Retail \& Leisure Property, 3(4), 331-343.

Schmidgall, R. S. (2006). Hospitality industry managerial accounting (6th ed.): Educational Institute - American Hotel \& Motel Association.

Schmidgall, R. S., \& Damitio, J. (1990). Current capital budgeting practices of major lodging chains. Real Estate Review, 20(3), 40.

Schmidgall, R. S., Damitio, J. W., \& Singh, A. J. (1997). What is capital expenditure? How lodging-industry financial executives decide. Cornell Hotel and Restaurant Administration Quarterly, 38(4), 28-33.

Schmidgall, R. S., \& Ninemeier, J. D. (1987). Budgeting in hotel chains: Coordination and control. Cornell Hotel and Restaurant Administration Quarterly, 28(1), 78-84.

Shane, S. A. (1996). Hybrid organizational arrangements and their implications for firm growth and survival: A study of new franchisors. Academy of Management Journal, 39(1), 216-234.

Skinner, R. C. (1990). The role of profitability in divisional decision making and performance. Accounting and Business Research(Spring), 135-141.

Slagmulder, R., \& Bruggeman, W. (1992). Justification of strategic investments in flexible manufacturing technology. Integrated Manufacturing Systems, 3(3), 4-15.

Slattery, P. (1992). Unaffiliated hotels in the UK. Travel and Tourism Analyst(1), 90102. 
Slattery, P. (1996). International development of hotel chains. In R. Kotas, R. Teare, J. Logie, C. Jayawardena \& J. Bowen (Eds.), The International Hospitality Business (pp. 30-35). London: Cassell.

Smith, C. W., \& Watts, R. L. (1982). Incentive and tax effects of executive compensation plans. Australian Journal of Management, 7, 139-157.

Smith Travel Research (2003). Property and portfolio research. Hotel \& Motel Management, 218(7), 24.

Tsuruni, Y. (1984). Multinational management: Business strategy and government policy. Cambridge, MA: Ballinger Press.

Van Wolferen, K. (1989). The enigma of Japanese power. Cambridge, MA: MIT Press.

Walker, G., \& Weber, D. (1984). A transaction cost approach to make or buy decisions. Administrative Science Quarterly, 29, 373-391.

Wallace, J. (1997). Adopting residual income-based compensation plans: Do you get what you pay for? Journal of Accounting and Economics, 24, 275-300.

Walsh, J. P., \& Seward, J. K. (1990). On the efficiency of internal and external corporate control mechanisms. Academy of Management Review, 15(3), 421458. 